\title{
Assessment of Menstrual Waste Disposal and the Environment: The Role of Adult Education in Nigeria
}

\author{
Adekunle Olatumile Ph.D \\ Department of Adult Education \\ Faculty of Education \\ Adekunle Ajasin University Akungba-Akoko \\ Ondo State, Nigeria \\ E-mail: adekunle.olatumile@aaua.edu.ng \\ Elizabeth Aanuoluwapo Ajayi \\ Department of Adult Education \\ Faculty of Education \\ Adekunle Ajasin University Akungba-Akoko \\ Ondo State, Nigeria \\ Email: elizabeth.ajayi@aaua.edu.ng \\ Phone: +234806 6392094
}

\begin{abstract}
The phenomenon of menstruation portends great impact on the environment and its calls for concern. Environmental effect of menstrual hygiene and related issues has been downplayed Nigeria. This study was conducted to assess menstrual waste disposal practices and it's implication on the environment. A self-constructed questionnaire was used to elicit information for the survey design research. While multistage sampling technique was used to select 194 participants of females within the age range of 20 and 59 in Akungba-Akoko, Ondo State. The four research questions raised for the study were answered descriptively while the two hypotheses were tested using inferential statistics at 0.05 level of significance. Finding revealed among others that though the female adults were aware of the environmental implication of indiscriminate menstrual waste disposal, they practices does not correlate with their awareness because menstrual waste disposal knowledge is not in public domain, while the knowledge gained is informal from older women who themselves lack adequate knowledge. It was therefore recommended among others, that adults deserves to be empowerment by Adult Education through Menstrual Waste Education (MWE) to improve hygiene as well as the environment during menstrual cycle due to the precarious situation it places on women.
\end{abstract}

Keywords: Menstrual hygiene; menstrual waste disposal; Menstrual Management Education; Environmental Adult Education

\section{I.Introduction}

Mensuration is a natural and biological phenomenon among female population of reproductive age, majority of who menstruate between two and seven days each month. This has to do with the monthly periodic bleeding arising out of the menstrual cycle. Houses, Mahon, and Cavill (2012) perused literature and posit that, globally, approximately 52\% of the female population ( $26 \%$ of the total population) is of reproductive age. Women menstruate on an average between 13 and 50 years of age in lowincome settings (but can start as early as from 8 years), amounting to a total of I400 days of menstruation in a woman's lifetime (Sumpter and Torondel 2013 cited in Rheinlander and Wachira 2015). This important phenomenon in the life human being that is linked to procreation has been a source of psychological trauma for women folk in the sense that it is strongly tied to culturally negative prejudices, stereotypes and attitudes.

There are several perceptions and practices, which sometimes result in adverse health and environmental challenges (Jogdand and Yerpude 20II). Superstitions, misinterpretations, illogical beliefs, stigmatization, taboos, myths, isolation, rejection, restriction, and marginalisation have greeted this natural phenomenon for women in Nigeria. These are reflected in the little or lack of awareness about menstruation for young girls experiencing it for the first time; lack of appropriate and sufficient information regarding menstrual hygiene which may engender incorrect and unhealthy behaviour during their menstrual period; incorrect information and skills which older women communicate to the younger women about menstrual hygiene; beliefs and practices of menstrual management, thus leaving them at the mercy of false attitudes (Runum and Msuega, 20I4; Lawan, Yusuf, Musa, 2010; Oche, Umar, Gana and Ango, 2012; Gultie, 2014). 
It has been stressed that historically, women and girls undergoing menstruation have used variety of materials to absorb menstrual fluid with implications for disposal and sanitation systems to both culture and the environment. These include sea sponges, leaves, corn cobs, wood ash, and pieces of cloth, cotton wool and tissue paper among others (Finley 2004 cited in Raina and Balodi, 2014). The modern disposable menstrual pads were invented in the $19^{\text {th }}$ century and are being improved upon overtime that premium is placed on advocacy for the affordability and use of disposable pads. Whereas, the use of reusable absorbent materials like clothes and reusable pad are not being emphasised. Reinforcing this problem is the fact that menstrual health and hygiene concerns have not been mainstreamed into environmental health management. Rumun and Msuega (20I4) observed that the last decade has seen an expansion in sanitarian issues to include the crucial environmental health in the areas of waste water and solid waste management, but there exist very little subtext on menstrual hygiene management.

This gap has inflicted setback on the health and wellbeing of the environment because lack of disposal facilities for used sanitary pads or cloths result in blockage of latrines and quick fullness of pits and cause environmental pollution (Rumun and Msuega (2014). This means the indiscriminate disposal of used sanitary pads, cloths, toilet rolls and other sanitary menstrual absorbents repudiates the environment. Raina and Balodi (2014) noted that lack of relevant menstrual waste disposal knowledge; inadequate disposal system and practices such as burning, burying, throwing in the waste bin, pit latrine or flushing result in clogged toilets and pollution of water bodies. These used absorbents may also be disposed in gutters, drainages, dunghills and refuse sites causing flooding and pollution. Various authors have carried out studies on the physiological health impact of menstrual waste on women and girls but the effect of menstrual waste on environmental health has been downplayed. Therefore, this study was set to provide answers to the following questions.

- Does the government encourage positive attitude towards menstrual waste disposal?

- What are the attitudes of females towards menstrual waste disposal strategies?

- Does menstrual waste disposal influence environmental sustainability?

- What can be done to achieve better menstrual waste disposal attitude?

Some scholars have also noted a relationship between age and educational status in the practice of menstrual waste disposal, hence, this study was also conducted to test the following null hypotheses:

- Ho I: Age has no significant influence on attitude towards menstrual waste disposal.

- Ho 2: Educational qualification has no significant influence on attitude towards menstrual waste disposal.

\section{Literature Review}

\section{I Environmental Consequences of Menstrual Waste}

Kaur, Kaur and Kaur (2018) combed literature on environmental consequences of menstrual waste, and identified the following: Sanitation systems were designed with urine and faeces in mind, they are unable to cope with the menstrual absorption materials. These absorption materials clog the sewer pipelines as they are unable to pass through and cause the system backflow. Materials like tampons, cotton wool, toilet paper, and other organic materials used for menstrual management might be decomposed in pit latrines/landfills except the plastic inlay of the commercial sanitary pads. Sanitary napkins might decompose over a period of about one year except its plastic lining in on-site sanitation.

In rural areas, pit latrines once full they were covered with soil and new pit was dug but due to land space limitations this was not practiced in most urban areas It was reported that some women and girls wrap their used menstrual cloths and packs in polythene bags before disposing in pit latrines which prevents them from decomposition. Nowadays, mostly women/girls prefer commercial sanitary pads and tampons which are made up of super absorptive materials like polyacrylate. These pads and tampons when flushed in the toilets they get saturated with liquid and swell up, thus resulting in sewage backflow, a serious health hazard. The adhesive wings and the perforated plastic layers in the commercial sanitary napkins are not easily biodegradable. The sewage blockages were mostly due to accumulation of excessive quantity of solid waste or sand which results in hardening of the sludge in the pits. Blockage of sewage system is a global problem and major contributing factor is flushing of menstrual products in toilets. Deodorized sanitary products used by women/girls contain chemicals used in bleaching such as organ chlorines which when buried in the soil disturb the soil micro flora and decomposition takes time.

People living alongside river banks throw menstrual waste into water bodies which contaminate them. These materials soaked with blood were breeding places for germs and pathogenic microbes. Sanitary products soaked with blood of an infected women/girl may contain hepatitis and HIV viruses which retain their infectivity in soil and live up to six months in soil. The clogged drainage with napkins has to be unblocked and cleaned manually by conservancy workers with their bare hands without proper protection and tools. This exposes the workers to harmful chemicals and pathogens. Incineration is a better technique to dispose of menstrual waste but burning of pads releases harmful gasses that effects health and environment. Burning of inorganic material at low temperature releases dioxins which are toxic and carcinogenic in nature. 


\subsection{Need for information and Education on Menstrual Hygiene and management}

Information is power, and knowledge is well known to influence attitude over time, hence, the need to provide education, accurate information and awareness creation is sine qua non to positive menstrual hygiene and waste behaviour. This has been canvassed by various authors and organizations. Increased access to information can challenge the myths that prevent women from interacting with men or performing household tasks while on their menstrual periods (Crofts 2012). Lack of information on menstrual preparedness and management is common amongst adolescent girls, while the shyness and embarrassment with which discussions about menstruation are avoided have made the situation even worse. In several cultures, various restrictions are imposed on women and girls during their menstruation period, thus resulting in poor personal hygiene and unsafe sanitary conditions leading to gynecological problems. Approximately half of the world's population of women has known from their own experience, good menstrual hygiene helps to perform optimally during their menstruation period (Raina and Balodi 20I4). Onyegegbu (2008) reiterated this when he posited that lack of flow of accurate and sufficient information regarding menstruation led to superstitious perception and beliefs about it in most rural communities. The implications of all these has continue to place girls in a state of confusion over their body and health, and for some women and young girls, lack of knowledge in combination with shame has led them to contracting terminal diseases.

\subsection{Empirical Studies on Menstrual Hygiene and Environment}

Various studies have been carried out on menstrual hygiene and materials used for menstrual flow absorption, Raina and Balodi (2014) in a study conducted in rural India reported that $59 \%$ of rural girls opined that sanitary pad should ideally be used during menstruation but $62 \%$ actually use old cloths during menstruation. In the same vein Lawan, Yusuf and Musa (2010) in a study carried in Nigeria found that $86.5 \%$ of the girls knew correctly that sanitary pad is the best sanitary absorbent recommended for adolescents. Whereas Rumun and Msuega (20I4) in a study carried out in Nigeria found that $70.5 \%$ of girls use sanitary pad, Oche, Umar, Gana and Ango (20I2) found that 87\% of the respondents use sanitary pad. Gultie (20I4) in his study carried out in Ethiopia reported that $97 \%$ of the respondents use sanitary pad.

On the methods used for disposing menstrual absorbents, Lawan, Yusuf and Musa (2010) reported that 7I\% dispose them with domestic wastes, Gultie (20I4) found that 5I.4\% throw used menstrual soaking materials in the toilet pan, 9.1\% throw them in the open field. Raina and Balodi (2014) reported that $56 \%$ of the respondents burn them while $16 \%$ throw them in routine waste.

On knowledge about menstruation, Rumun and Msuega (2014) reported that $93 \%$ of the respondents are knowledgeable, Gultie (20014) in the same vein found that girls are knowledgeable. Oche, Umar, Gana and Ango (2012) found that $65 \%$ of the respondents had high knowledge. On the significance of age and education on knowledge of menstruation, Oche, Umar, Gana and Ango (2012) found that age and education of respondents were not statistically significant with respect to the knowledge of menstruation and its management. However Lawan, Yusuf and Musa (2010) found that the respondent's knowledge was significantly associated with the age group of the respondents. George and Murcott (I992) related that the education of young women about menstruation and its waste disposal is lacking.

\section{Method and Material}

This study employed a cross sectional survey with a population of females residing in Akungba-Akoko area of Ondo State between the ages of 20 and 59. Multistage sampling techniques was used for the study. The first stage was proportionate stratified random sampling based on quarters in Akungba-Akoko. The second stage was purposive sampling technique to select five quarters representative of the area. The third stage was accidental sampling technique used to select I94 participants from the communities as stated below:

\begin{tabular}{cc}
\hline Quarters & Total \\
\hline Akwa & 39 \\
\hline Araromi & 45 \\
\hline Ibaka & $5 \mathrm{I}$ \\
\hline Ilale & 27 \\
\hline Okusa & 32 \\
\hline & I94
\end{tabular}

The instrument used was a self-constructed questionnaire consisting of closed ended 2I items with multi-choice responses covering issues around the attitude towards menstrual waste disposal and it's implication on the environment. Responses received were analysed using frequency count and simple percentage for the research questions and the hypotheses were tested using one way Analysis of Variance (ANOVA) at 0.05 level of significance. 
4. Data Analysis and Interpretation Bio-data Analysis

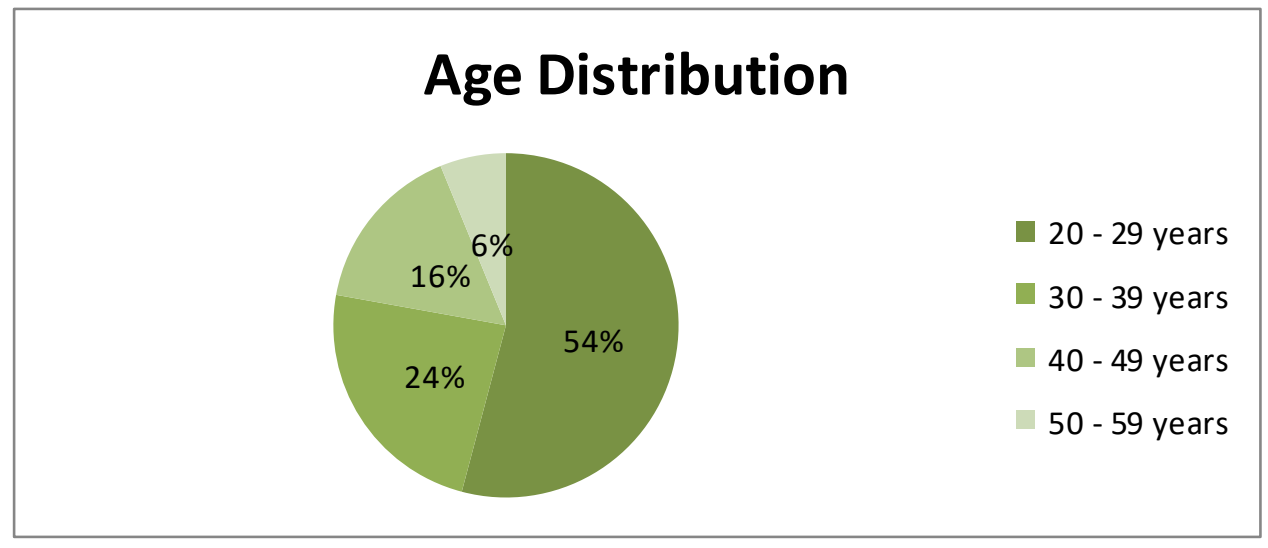

Source: Field work (2018)

Fig. I: Chart of participants age distribution

Figure. I revealed that majority of the participants is females within the age range of 20 and 29 years followed by those within the age range of 50 and 59.

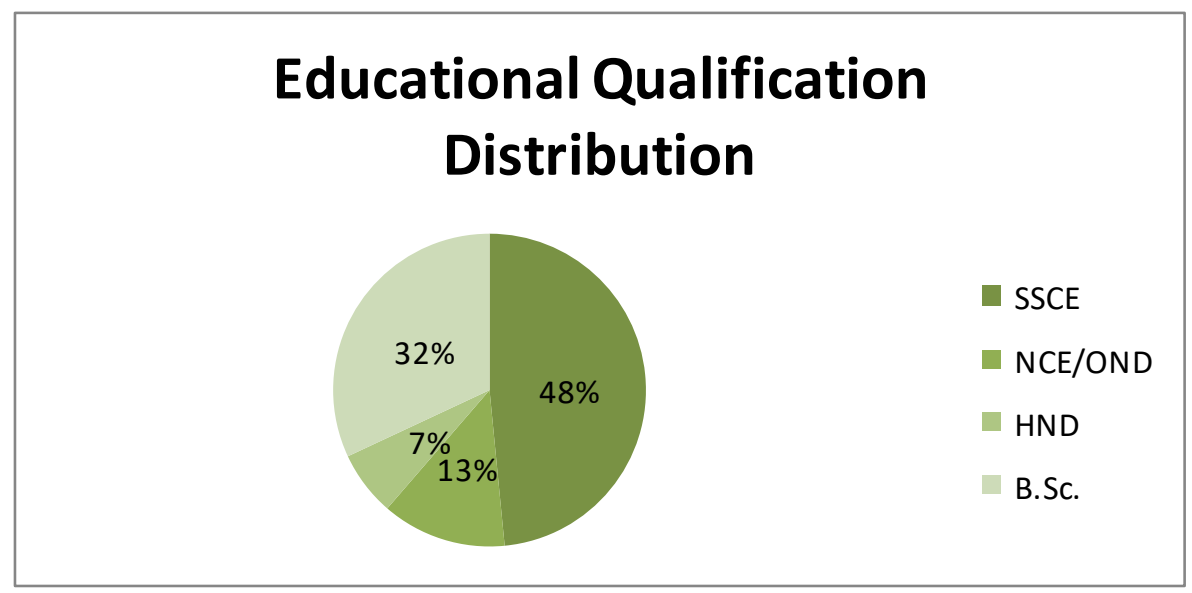

Source: Field work (2018)

Figure. 2: Chart of participants educational qualification distribution

Fig. 2 reveals that majority of the participants have Bachelor's degree while minority have HND.

Research Question I: Does the government encourage positive attitude towards menstrual waste disposal?

Table I: Response on government's attitude and menstrual waste disposal

\begin{tabular}{cccc}
\hline Items & Responses & Frequency & Percentage \\
\hline Government attitude towards curbing & Yes & 66 & 34 \\
\cline { 2 - 4 } environmental issues is encouraging & No & I28 & 66 \\
\hline $\begin{array}{c}\text { There is effective policy or regulatory measures } \\
\text { for managing menstrual waste disposal }\end{array}$ & Yes & 75 & 38.7 \\
\cline { 2 - 4 } & No & I I9 & 61.3 \\
\hline Lack of social amenities contributes to inadequate & Yes & I7I & 88.1 \\
\hline
\end{tabular}




\begin{tabular}{cccc}
\hline disposal of menstrual waste & No & 23 & I I.9 \\
\hline \multirow{2}{*}{$\begin{array}{c}\text { Government attitude is effective in creating } \\
\text { hygienic menstrual waste disposal }\end{array}$} & Effective & 39 & 2.6 \\
\cline { 2 - 4 } & Not Effective & I50 & 77.3 \\
\cline { 2 - 3 } & Strongly Effective & 5 & 20.1 \\
\hline \multirow{2}{*}{$\begin{array}{c}\text { Government awareness concerning menstrual } \\
\text { waste disposal }\end{array}$} & Yes & I.46 \\
\cline { 2 - 4 } & No & 90 & 30.9 \\
\hline Grand Average & Positive & 60 & 69.1 \\
\hline
\end{tabular}

Source: Field work (2018)

A negative grand percentage of 69.I affirmed that government does not encourage positive attitude towards menstrual waste disposal especially with the lack of awareness creation, policy, amenities among others from the government. The reason for this result may be viewed from the perspective that government and organizations have not been visible in curbing environmental issues especially in rural and semi urban areas and even scholars have limited literature in these areas. Unlike the government and organizations in developed countries such as Women Environmental Network (WEN) in UK who sensitizes on issues such as this. This finding showed, lack of awareness through the government and Non-governmental organizations for majority of females. This is also accounted for in one of the statements for research question four, where participants enjoyed government to have and implement policies that will help curb the menace of seeing menstrual waste in dustbins, on the road or in water.

Research Question 2: What are the attitude of females towards menstrual waste disposal strategies?

Table 2: Response on environmental compliant menstrual waste disposal practice

\begin{tabular}{|c|c|c|c|}
\hline Items & Responses & $\mathrm{F}$ & Percentage \\
\hline \multirow[t]{3}{*}{ Type of sanitary protection used } & Disposable sanitary napkins & 180 & 92.8 \\
\hline & Tampon & 6 & 3.1 \\
\hline & Cloth & 8 & 4.1 \\
\hline \multirow{4}{*}{$\begin{array}{c}\text { Reason why menstrual waste disposal is not } \\
\text { discussed }\end{array}$} & Taboo & 17 & 8.8 \\
\hline & Ritually unclean & 39 & 20.1 \\
\hline & Embarrassing & 93 & 47.9 \\
\hline & Attached myth & 45 & 23.2 \\
\hline \multirow{2}{*}{$\begin{array}{l}\text { Menstrual waste can be used for rituals if disposed } \\
\text { indiscriminately }\end{array}$} & Yes & 183 & 94.3 \\
\hline & No & II & 5.7 \\
\hline \multirow{5}{*}{ Usual method for menstrual waste disposal } & Flushing in toilet & 65 & 33.5 \\
\hline & Burying & 20 & 10.3 \\
\hline & Burning & 86 & 44.3 \\
\hline & Disposing in stream/gutter & $2 \mathrm{I}$ & 10.8 \\
\hline & Disposal on land & 2 & 1.0 \\
\hline \multirow{2}{*}{$\begin{array}{l}\text { I am aware of the environmental concerns of } \\
\text { menstrual waste disposal }\end{array}$} & Yes & $\mathrm{I} 47$ & 75.8 \\
\hline & No & 47 & 24.2 \\
\hline
\end{tabular}




\begin{tabular}{ccccc}
\hline Grand Average & Positive & 170 & 87.6 \\
\cline { 2 - 5 } & Negative & 24 & I2.4 \\
\hline
\end{tabular}

Source: Field work (2018)

A positive grand average percentage of 87.6 revealed that females have positive attitude towards menstrual waste disposal. This revealed that most females are aware of what to use; the need and how to dispose menstrual waste, even though it may not be environmentally compliant or discussed in public. This confirms that females have learnt to do these mostly through informal learning from older women and friends. Montgomery, Ryus, Dolan, Dopson and Scott (2012) confirmed that what women use for menstrual fluid has changed from cloth to disposable sanitary napkin. Also Lawan, Yusuf and Musa (2010) supported that in a study carried in Nigeria which found that $86.5 \%$ of the girls knew correctly that sanitary pad is the best sanitary absorbent recommended for adolescents. Finding revealed a negative disposal practice such as flushing, burning and disposing in water ways among others which are not been ideal or environmentally compliant This is in line with Dargan, Selvaraj and Pratap's finding in 2015 that women sanitary napkins are thrown in toilets, rivers or burned, which are practices that are not environmental friendly. Although in relation to research question one, it can be observed that the absence of facilities such as incinerator, laundry machine for reusable sanitary materials among others and lack of enlightenment, may account for the lack of good practice among females. Whereas this present practices have impending danger for the earth.

Research Question 3: Does menstrual waste disposal influence environmental sustainability

Table 3: Response on menstrual waste disposal and environmental sustainability

\begin{tabular}{|c|c|c|c|}
\hline Items & Responses & $F$ & percentage \\
\hline \multirow{2}{*}{$\begin{array}{l}\text { Inadequate menstrual waste disposal have } \\
\text { environmental implication }\end{array}$} & Yes & 170 & 87.6 \\
\hline & No & 24 & I2.4 \\
\hline \multirow{2}{*}{$\begin{array}{c}\text { Menstrual waste disposal on land serves as barrier for } \\
\text { agriculture }\end{array}$} & Yes & $\mathrm{I} 24$ & 63.9 \\
\hline & No & 70 & 36.1 \\
\hline \multirow{2}{*}{$\begin{array}{l}\text { Menstrual waste disposal in streams/sea cause havoc to } \\
\text { aquatic animal }\end{array}$} & Yes & I58 & 81.4 \\
\hline & No & 70 & 18.6 \\
\hline \multirow[t]{2}{*}{ Flushing if sanitary napkins causes blockage in toilets } & Yes & I74 & 89.7 \\
\hline & $\mathrm{No}$ & 20 & 10.3 \\
\hline \multirow{2}{*}{$\begin{array}{l}\text { Unhygienic menstrual waste disposal creates healthy } \\
\text { and pollution free environment }\end{array}$} & Yes & 25 & 12.9 \\
\hline & No & I69 & 87.1 \\
\hline \multirow[t]{2}{*}{ Grand Average } & Positive & I59 & 82.0 \\
\hline & Negative & 35 & 18.0 \\
\hline
\end{tabular}

Source: Field work (2018)

A positive grand average of $82 \%$ revealed that participants agreed that menstrual waste disposal influence environmental sustainability. Research question three gave a conflicting view in line with research question two, in that the participants know that indiscriminate disposal of menstrual waste poses danger for the survival and sustainability of the environment, yet they do not practice sustainability in its disposal. The findings here affirmed the statements of scholars such as Dargan, et.al. (2015) that indiscriminate disposal of menstrual waste becomes barrier for agriculture because it reduces soil fertility; it kills aquatic animals and contaminate drinkable water; and its consistent flushing in toilet causes blockage which later constitute pollution and is unhealthy. This is why Lumutenga, Khaitsa, Muwazi, Wakoko-Studstill, Naigaga, Hossfield and Ralston (2018) among other scholars, are advocating for organic materials such as reusable cloth pad which will be made up of cotton, hemp, wool, bamboo, micro-fibre and the likes. This is believed to be potent for a sustainable environment and healthy female body. 
Research Question 4: What can be done to achieve better menstrual waste disposal attitude?

Table 4: Response on achieving better menstrual waste disposal practice

\begin{tabular}{|c|c|c|c|}
\hline Items & Responses & $\mathrm{F}$ & Mean \\
\hline \multirow{2}{*}{$\begin{array}{l}\text { There is need for awareness via media on } \\
\text { menstrual waste disposal }\end{array}$} & Yes & 180 & 92.8 \\
\hline & No & $\mathrm{I} 4$ & 7.2 \\
\hline \multirow{2}{*}{$\begin{array}{c}\text { Knowledge on menstrual waste disposal } \\
\text { unnecessary in schools }\end{array}$} & Yes & 17 & 8.8 \\
\hline & No & 177 & 91.2 \\
\hline \multirow{2}{*}{$\begin{array}{l}\text { Menstrual waste disposal has to do more with } \\
\text { availability of facilities }\end{array}$} & Yes & 94 & 51.5 \\
\hline & No & 100 & 48.5 \\
\hline \multirow{5}{*}{$\begin{array}{l}\text { Which method is best for menstrual waste } \\
\text { disposal }\end{array}$} & Recycling & 37 & I9.I \\
\hline & Burning in incinerator & 128 & 66.0 \\
\hline & Burying & 19 & 9.8 \\
\hline & Land filling & 8 & 4.1 \\
\hline & Disposal in flowing water & 2 & 1.0 \\
\hline \multirow{2}{*}{$\begin{array}{l}\text { Government needs to implement a policy in } \\
\text { relation to menstrual waste disposal }\end{array}$} & Yes & $\mathrm{I} 47$ & 75.8 \\
\hline & No & 47 & 24.2 \\
\hline \multirow[t]{2}{*}{ Grand Average } & Positive & 150 & 77.3 \\
\hline & Negative & 44 & 22.7 \\
\hline
\end{tabular}

Source: Field work (2018)

Participants according to the findings from research question 4 acknowledged that there are ways to have a better practice of the use of this inorganic sanitary material. The positive grand of $77.3 \%$ revealed that majority of the respondents identified pos sible steps toward achieving a better menstrual waste disposal attitude. Some of the ways are creating awareness, inculcating knowledge through education, provision of facilities and implementation of policies are more likely to enhance good practice of menstrual waste disposal. This correlates with Dargan, et. al (2015) that proffered solutions for menstrual waste disposal as a multi approach involving the use of appropriate product options, educating on its disposal with an input of women in the sanitation and waste management system.

Ho I: Age has no significant influence on attitude towards menstrual waste disposal.

Table 5: ANOVA of menstrual waste disposal attitude by Age

\begin{tabular}{lrrrrc}
\hline \multicolumn{1}{c}{ Age } & Sum of Squares & df & Mean Square & F & Sig. \\
\hline Between Groups & 7.749 & 3 & 2.583 & 2.331 & .058 \\
Within Groups & 210.504 & I90 & I.108 & & \\
Total & 218.253 & I93 & & & \\
& & & & & \\
\hline
\end{tabular}

$$
\alpha=.05
$$

Table 5 shows that an $\mathrm{F}$ value of $2.33 \mathrm{I}$ and a $\mathrm{p}$ value of .058 testing at an alpha level of .05. The $\mathrm{p}$ value is higher than the alpha level, so the null hypothesis which stated that 'Age has no significant influence on attitude towards menstrual waste disposal' is accepted. This confirms the finding of Oche, Umar, Gana and Ango (2012) who found that age of females was not statistically significant with respect to the knowledge of menstruation and its' management. The finding controverts that of Lawan, Yusuf and Musa (2010) that the respondents' knowledge was significantly associated with the age group of the respondents. This may be seen form the aspect of informal education, where the younger females have always learnt form the older, hence their practice rubs off on the younger. Although most of the older women use cloths for their menstrual fluid, they 
still purchase sanitary pads for the younger ones and because they lack adequate knowledge on its disposal, they cannot inculcate a better knowledge in the young ones.

H. 2: Educational qualification has no significant influence on attitude towards menstrual waste disposal. Table 6: ANOVA of menstrual waste disposal attitude by educational qualification

\begin{tabular}{lrrrrc}
\hline \multicolumn{1}{c}{ Educational Qualification } & Sum of Squares & df & Mean Square & F & Sig. \\
\hline Between Groups & 2.262 & 4 & .566 & .495 & .039 \\
Within Groups & $2 \mathrm{I} 5.990$ & $\mathrm{I} 89$ & I.I43 & & \\
Total & 218.252 & I93 & & & \\
\end{tabular}

$$
\alpha=.05
$$

Table 6 shows that an F value of .495 and a p value of .039 testing at an alpha level of .05. The p value is lesser than the alpha level, so the null hypothesis which stated that 'educational qualification has no significant influence on attitude towards menstrual waste disposal' is rejected. This implies that educational qualification has significant influence on attitude towards menstrual waste disposal. This is at variance with the findings of Oche, Umar, Gana and Ango (2012) who found that education of females was not statistically significant with respect to the knowledge of menstruation and its management. The reason for this may be seen from the perspective of Woeller, Miller, Robertson-Smith and Bolhman (2015) that advertisement on sanitary pad portrays it has been convenient, desirable and without it menstrual periods can be bad for females. This reveals that though education via the media has made females aware of the benefit of sanitary pads, it has failed to make them functionally literate about the implication of its disposal on the planet earth. This supports George and Murcott (I992) that education of young women about menstruation is adequate but its waste disposal is lacking.

\section{Conclusion}

Menstruation is a natural process in women's life but due to environmental illiteracy; inadequate waste disposal; negligence on part of the government on awareness and environmental policy issue; and poor health facilities such as menstrual cup, reusable sanitary napkins and incinerators especially in rural semi urban areas (among which is Akungba-Akoko) we have negative consequences of menstrual waste disposal. It is necessary for the professionals to acknowledge the place of education (formal, informal and non-formal) in ensuring a free environment requiring the support of the government, non-governmental organizations and media outfits. This will ensure having menstrual waste disposal in environmental policy and create awareness about it. In the light that adults are mostly involved, it behaves Adult education as a profession to have programmes related women and environmental education to create a safe sanitary and hygienic environment.

\section{Recommendation: The role of Adult Education}

It is true that menstruation not a choice for all females because it is a sign of the ability to reproduce, but managing its waste is a choice. Women thus deserve empowerment to better knowledge and skill on menstruation hygiene and management to their wellbeing and that of the environment during their menstrual cycle. This brings the need for Adult Education to provide Menstrual Waste Education (MWE), which would be germane for addressing the precarious situation of waste disposal menstrual period placed on women.

This type of Adult Education would have a content that exposes adults to the:

- Ability of selecting and using hygienic menstrual absorbents taking into consideration, it's environmental friendliness and proper disposal;

- Advantages and disadvantages of reusable and disposable sanitary menstrual absorbents and its implication for the wellbeing of the environment;

- Different methods of disposing sanitary menstrual absorbents, its' advantage and disadvantages as well as implication for the wellbeing of the environment;

- Implications of improper disposal of sanitary menstrual absorbents on the environment and environmental resources, like soil, underground water and rivers;

- The need to make provision for menstrual waste disposal facilities such as incinerator in their homes, offices, schools and every public facility

The content of MWE should also provide skills that ensure:

- Older women are aware and can communicate effectively issues that concern menstruation to the younger ones (male and females) in order to demystify and de-stigmatise menstruation; 
- Young women are empowered to speak out on issues concerning menstruation;

- There is for the males to understand menstrual hygiene so that they will know their responsibilities in giving support to their sisters, wives, mates, daughters, employees, subordinates among others during their menstrual periods;

- Changes of tight held superstitions attached to menstruation by the society;

- All citizens both old and young, male and female support and advocate for the provision of appropriate infrastructure and facilities that will facilitate smooth menstrual hygiene and management to enhance environmental sustainability.

MWE can be delivered through the following means:

- Educative programmes, talks, jingles, spots on menstrual hygiene, management and waste disposal on radio and television;

- Menstrual hygiene, management and waste disposal awareness on social media such as facebook, twitter, instagram and whatsapp;

- Messages on menstrual hygiene, management and waste disposal should feature on billboards, posters, leaflets and fliers;

- Mementos like vests, caps, jotters, exercise books, pens, with menstrual hygiene, management and waste disposal messages should be made available to the public;

- Special community programmes like day celebrations and festival should feature advocacy on menstrual hygiene and management campaign;

- Gender advocacies should mainstream education on menstrual issues in their programmes

- Train the trainer programmes on menstrual hygiene, management and waste disposal should be organised for teachers, community leaders, religious leaders, community health extension workers and other groups that can reach women and girls

- Religious outlets like churches and mosques must mainstream menstrual hygiene, management and waste disposal issues in their programmes

- School curricula especially at primary and secondary levels must include education on menstrual hygiene, management and waste disposal

- Laubach approach of each-one-teach-one should be aggressively applied in delivering MWE. A person that is knowledgeable on menstrual hygiene, management and waste disposal issues can educate the other that is not knowledgeable.

MWE should be a lifelong education as it revolves round every member of the society; male and female, young and old. Therefore, the delivery system and content should be used together rather than in isolation to achieve total result of mutual reinforcement.

\section{References}

Crofts, T. (2012). Menstruation Hygiene Management for School Girls in Low-Income Countries. Leistershire: Water Engineering and Development Centre, Loughborough University.

Dargan, T. Selvaraj, J. and Singh, D. (June 5, 2015). World Environment Day 2015: Menstrual Waste Disposal and the Environment. Retrieved on January 3I, 2018 from www.india.com/news/india/world-environment-day-20I5menstrual-waste-disposal-and-the-environment-409523

George, A. and Murcott, A. (1992). Monthly strategies for discretion: Shopping for sanitary towels and tampons. The Sociological Review 4O(I). Retrieved on January 3I, 2018 from https://doi.org/I0.I I I/jI467-954x.I992.tb02949.x

Gultie, T. K. (2014). Practice of menstrual hygiene and associated factors among female Mehalmeda high school students in Amhara regional state, Ethiopia. Science Joumal of Public Health. 2(3), I89-195.

Houses, S., Mahon, T. and Cavill, S. (2012). Menstrual Hygiene Matters: A Resource for Improving Menstrual Hygiene around the World. UKAid.

Jogdand, K. and Yerpude, P. (20II). A Community Based Study on Menstruation Hygiene Among Adolescent Girls. Indian Journal of Matemal and Child Health. 13 (3) I-6.

Kaur, R., Kaur, K. and Kaur, R. (2018). Menstrual hygiene, management and waste disposal: Practices and challenges faced by Girls/women of developing countries. Retrieved on January 3I, 2018 from doi: I0.I 155/2018/I730964 
Lawan, U M., Yusuf, N W. and Musa, A. B. (2010). Menstruation and menstruation hygiene amongst adolescent school girls in Kano, North-western, Nigeria. African Joumal of Reproductive Health I4(3), 20I-208.

Lumutenga, N., Khaista, M., Muwazi, R. Wakoko-Studstill, F. Naigaga, I., Hossfold, L. and Ralston, M. (2018). Women empowering women through reusable sanitary pads. Journal of Community Engagement \& Scholarship IO(I), I4 I-I5I.

Montogomery, P., Ryus, C. R., Dolan, C. S., Dopson, C. and Scott, L. (2012). Sanitary pads intervention for girl's education in Ghana: A pilot study. Plos one 7(I0) Retrieved on January 3I, 2018 from doi: I0.I37I/journal.pone.0048274

Oche, M. O. Umar, O. O., Gana, G. J. and Ango, J. T. (2012). Menstrual health: The unmet needs of adolescent Girls' in Sokoto, Nigeria. Scientific Research and Essays 7(3), 4I0-4I8.

Onyegegbu, N. (2008). Menstruation and menstrual hygiene among women and young females on Rural Eastern Nigeria. Journal of Science Teachers Association of Nigeria (JSTAN) 28, 193-206.

Raina, D. and Balodi, G. (20I4). Menstrual hygiene: Knowledge, practices and restrictions amongst girls of Dehradun, Uttarakhand, India. Global Journal of Interdisciplinary Social Sciences 3(4), I56-I62.

Rheinlander, T. and Wachira, M. (2015). Menstrual hygiene. Global Health Minders. Retrieved on January 3 I, 2018 from http://GHM-MenstrualHygiene-Brief.pdf

Rumun, A. J. and Msuega, A. P. (2014). Menstrual knowledge and practices among adolescent females in Makurdi Metropolis. Global Journal of Interdisciplinary Social Sciences 3(3), I I3-I2I.

Woeller, K., Miller, A., Robertson-Smith, A. and Bohman, L. (2015). Impact of advertising on tampon wear-time practices. Clinical Medicine Insights Women Health 8, 29-31. Retrieved on January 3I, 2018 from doi: I0/4I37/CMWH.S25I23

\section{Copyrights}

Copyright for this article is retained by the author(s), with first publication rights granted to the journal. This is an open-access article distributed under the terms and conditions of the Creative Commons Attribution license (http://creativecommons.org/licenses/by/4.0/). 